UDC 546.05

\author{
O.V. Makarchuk, T.A. Dontsova, I.M. Astrelin \\ National Technical University of Ukraine "KPI", Kyiv, Ukraine
}

\title{
MAGNETIC CLAY SORBENT FOR THE REMOVAL OF DYES FROM AQUEOUS SOLUTIONS
}

Background. Saponite is low-cost sorbent and is effective for removal of organic pollutants, dyes, heavy metal ions from water. However, saponite sorbents are not widely used. The saponite particles waste is removed from the solution after sorption process with considerable difficulties due to their high dispersion. To overcome this difficulty clay particles can be magnetized by magnetite, then by simple procedure (magnetic separation) removed from the water.

Objective. The purpose of this article is synthesis magnetically controlled sorbents based on saponite and magnetite $\left(\mathrm{Fe}_{3} \mathrm{O}_{4}\right)$ by different schemes; the characterization of obtained sorbents and determination of their adsorption properties towards dyes; choice of magnetic module design.

Methods. In the paper modern physic-chemical and experimental research methods were used: X-ray fluorescence, X-ray analysis, physical adsorption/desorption of Nitrogen, sorption and magnetic separation process.

Results. It was found that magnetic modification (in an amount of $2 \%$ magnetite by weight) of saponite by impregnation method allows obtaining mesoporous sorbents with good sorption and magnetic properties. The detected adsorption capacity of magnetically sorbents for all types of dyes (anionic, cationic and nonionic) was 1.5-2.5 times bigger than that for native saponite.

Conclusions. It is shown that modification of saponite by magnetite not only improves its magnetic properties, but also increases its absorption characteristics (specific surface area, sorption capacity). The impregnation method allows obtaining magnetic clay sorbent with better sorption and magnetic characteristics. The pyramid magnetic module was the most effective magnetic module design for deposition of spent magnetic sorbent.

Keywords: saponite; magnetite; dyes; magnetic clay sorbent; adsorption; magnetic separation.

\section{Introduction}

The rapid development of textile, light, printing and other industries raises the question of wastewater purification of organic dyes which relate mainly to highly toxic substances. Wastewater from these industries poses serious environmental problems and hazards for human and animal health.

The dyes removal methods are included: coagulation [1], oxidative methods [2], biological treatment [3], sorption methods [4] and so on. Among these methods the adsorption is the most effective for deep removal of dyes from aqueous solutions [5]. Activated carbon, synthetic adsorbents, silica gel, alumogel are used as sorbents [6, 7]. However, the use of activated carbon and synthetic sorbents in a large scale is economically burdensome, so we need to find new effective and inexpensive sorption materials. In our opinion, natural clay minerals, in particular, saponites satisfy these requirements.

Saponite is a natural aluminum magnesium silicate of the montmorillonite group with a layered subclass (type 2:1). Saponite has chemical formula $\mathrm{NaMg}_{3}\left[\mathrm{AISi}_{3} \mathrm{O}_{10}\right](\mathrm{OH})_{2} \cdot 4 \mathrm{H}_{2} \mathrm{O}$. Saponite is cheaper than synthetic sorbents and it can compete with them in the efficiency of organic pollutants, dyes, heavy metal ions removal from water [8-10]. However, saponite sorbents are not widely used. The saponite particles waste is removed from the solution after sorption process with considerable difficulties due to their high dispersion. To overcome this difficulty clay particles can be magnetized by magnetite, then by simple procedure (magnetic separation) removed from the water.

It is known [11], magnetite has strong magnetic properties, such as saturation magnetization $J_{\mathrm{s}}=451-454 \mathrm{kA} \cdot \mathrm{m}^{-1}$, coercive force $H_{\mathrm{c}}=$ $=1.6 \mathrm{kA} \cdot \mathrm{m}^{-1}$, specific magnetic susceptibility $\chi=$ $=(0.18-1.28) \cdot 10^{-2} \mathrm{~m}^{3} \cdot \mathrm{kg}^{-1}$. This gives reason to get magnetic sorbents with a small amount of magnetite and, hence, low cost.

So, for creation of low-cost and effective sorbents it is suggested to modify the native saponite by magnetite.

\section{Formulation of the problem}

The purpose of this article is synthesis of magnetically controlled sorbents based on saponite and magnetite $\left(\mathrm{Fe}_{3} \mathrm{O}_{4}\right)$ by different schemes; the characterization of obtained sorbents and determination of their adsorption properties towards dyes; choice of magnetic module design.

\section{Materials and methods}

The natural saponite clay is used for synthesis of magnetically sorbents (MCS). It was crushed 
and sieved to a particle size less than 230 mesh $(63 \mu \mathrm{m})$. The magnetite was obtained by chemical deposition from the aqueous solution of $\mathrm{FeSO}_{4} \cdot 7 \mathrm{H}_{2} \mathrm{O}$ and $\mathrm{FeCl}_{3} \cdot 6 \mathrm{H}_{2} \mathrm{O}$ (with ratio of $\left.\mathrm{Fe}^{3+} / \mathrm{Fe}^{2+}=2\right)$. Then solution of $\mathrm{NH}_{3} \cdot \mathrm{H}_{2} \mathrm{O}(25 \% \mathrm{wt}$. $)$ was added drop wise until the formation magnetite $\mathrm{Fe}_{3} \mathrm{O}_{4}$ (pH 9-10).

The synthesis of MCS samples was carried out in two ways: co-precipitation and impregnation methods. As a result were obtained MCS 2 and MCS 3 (Fig. 1).

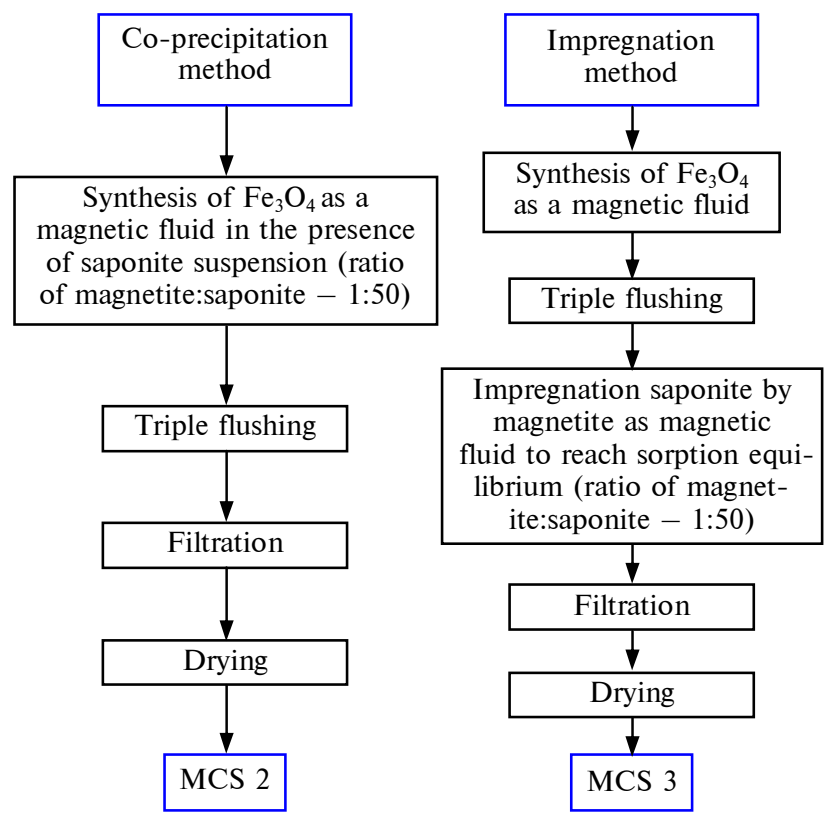

Fig. 1. Scheme of the MCS synthesis

The mass content of chemical elements in the saponite and MCS samples was determined by EXPERT 3L analyzer by method of non-destructive energy dispersive X-ray fluorescence without standards. Resolution of Si-PIN detector for line $K_{\mathrm{a}} K_{\mathrm{n}}=5.9 \mathrm{keV}$ was $155 \mathrm{eV}$.

Powder X-ray diffraction (XRD) patterns of sorbents were received using diffractometer Rigaku Ultima IV, equipped with $\mathrm{CuK} \alpha$ radiation $(40 \mathrm{kV}$, $30 \mathrm{~mA}$ ).

Structural and adsorption characteristics of saponite and MCS samples were determined with the automatic sorptometer Quantachrome Autosorb (Nova 2200e) by physical adsorption/desorption of Nitrogenin its boiling point ( $T=77 \mathrm{~K}$ ).

Sorption properties of native saponite clay and MCS samples were investigated by constructing of adsorption isotherms and kinetic curves of dyes: Malachite green (cationic triarylmethanedye), Congo red (anionic diazodye) and Indigo carmine (nonionic vatdye).
Magnetic separation process was studied in magnetic modules of two designs: invariable $(66 \mathrm{mT})$ and variable strength gradient (from 20 to $200 \mathrm{mT}$ ) of external magnetic field (EMF).

\section{Results and discussions}

Sorbents characterization. All samples (native saponite clay, MCS 2, MCS 3) were characterized $\mathrm{X}$-ray fluorescence, X-ray analysis and physical adsorption/desorption of Nitrogen. The results of chemical composition simples of sorbents are given in Table 1.

Table 1. Chemical composition of natural saponite clay and MCS simples

\begin{tabular}{|c|c|c|c|}
\hline \multirow{2}{*}{ Element } & Saponite & MCS 2 & MCS 3 \\
\hline & \multicolumn{3}{|c|}{ Mass fraction, $\%$} \\
\hline $\mathrm{Mg}$ & $5.3-6.2$ & $4.1-4.3$ & $4.4-5.1$ \\
\hline $\mathrm{Al}$ & $4.9-5.8$ & $4.6-4.63$ & $4.05-4.1$ \\
\hline $\mathrm{Si}$ & $20.7-24.7$ & $23.03-23.4$ & $22.62-26.00$ \\
\hline $\mathrm{S}$ & $\leq 0.2$ & $\leq 0.5$ & $\leq 0.01$ \\
\hline $\mathrm{Ca}$ & $24.6-24.9$ & $20.5-23.6$ & $22.00-23.16$ \\
\hline $\mathrm{Ti}$ & $2.2-3.1$ & $2.4-2.7$ & $2.32-2.86$ \\
\hline $\mathrm{V}$ & $0.2-0.2$ & $0.18-0.2$ & $0.13-0.18$ \\
\hline $\mathrm{Cr}$ & $\leq 0.01$ & $0.07-0.08$ & $0.06-0.09$ \\
\hline $\mathrm{Mn}$ & $0.77-1.21$ & $0.7-0.93$ & $0.76-0.89$ \\
\hline $\mathrm{Fe}$ & $39.9-41.2$ & $42.4-44.0$ & $41.8-44.4$ \\
\hline $\mathrm{Ni}$ & $0.05-0.12$ & $0.06-0.07$ & $0.05-0.06$ \\
\hline $\mathrm{Cu}$ & $0.11-0.14$ & $0.10-0.11$ & $0.08-0.12$ \\
\hline $\mathrm{Zn}$ & $0.09-0.18$ & $0.1-0.11$ & $0.08-0.1$ \\
\hline $\mathrm{Ga}$ & $\leq 0.02$ & $\leq 0.02$ & $\leq 0.02$ \\
\hline $\mathrm{Rb}$ & $\leq 0.02$ & $\leq 0.02$ & $\leq 0.02$ \\
\hline $\mathrm{Sr}$ & $0.05-0.1$ & $0.02-0.03$ & $0.03-0.05$ \\
\hline $\mathrm{Y}$ & $0.02-0.04$ & $0.01-0.02$ & $0.01-0.02$ \\
\hline $\mathrm{Zr}$ & $0.03-0.07$ & $0.02-0.04$ & $0.03-0.05$ \\
\hline In & $\leq 0.02$ & $\leq 0.02$ & $\leq 0.02$ \\
\hline
\end{tabular}

According to the datain Table 1, the iron content in MCS 2 and MCS 3 increases and is about $42-44 \%$. It is more than $2-4 \%$ in saponite (iron content was about 40-41\%).

The diffractograms of samples are presented in Fig. 2. On diffractogram of native saponiteclay (Fig. 2, curve 1) phases identified: saponite, montmorillonite, calcite, quartz, iron (II) oxide. On XRD pattern of MCS 2 (Fig. 2, curve 2) all phases of native saponite were found, and also peaks for hematite $\left(\alpha-\mathrm{Fe}_{2} \mathrm{O}_{3}\right)$ and magnetite $\left(\mathrm{Fe}_{3} \mathrm{O}_{4}\right)$ were detected. On XRD pattern of MCS 3 (Fig. 2, curve 3) all phases of nature saponite clay are also identified 
and peaks belonging exclusively magnetite $\mathrm{Fe}_{3} \mathrm{O}_{4}$ were found. The size of magnetite crystallites in composite sorbents was $2-4 \mathrm{~nm}$.

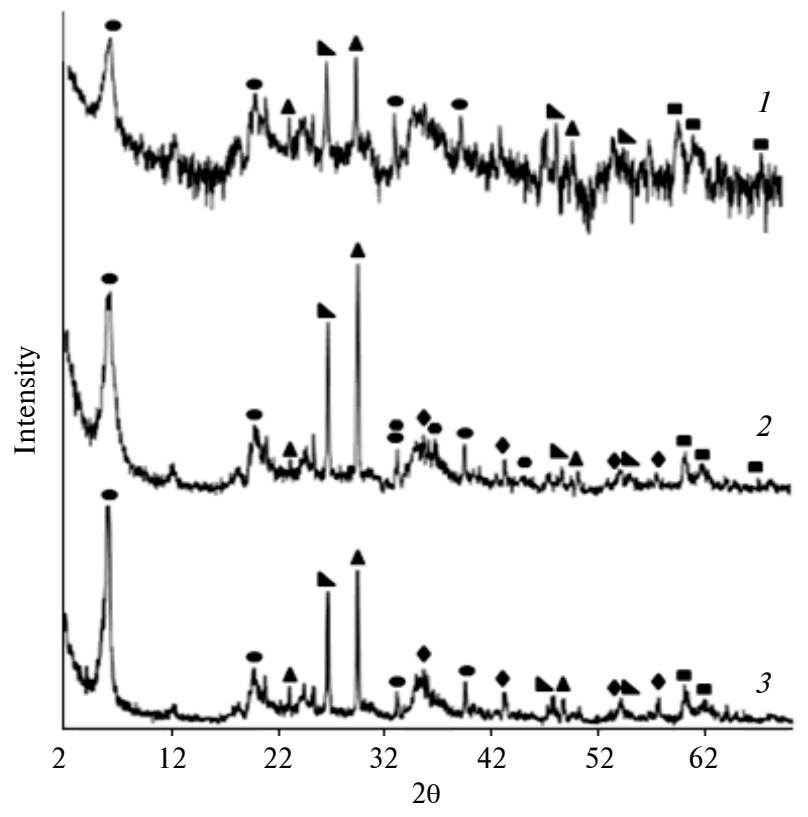

Fig. 2. The XRD patterns of saponite clay (1); MCS 2 (2), MCS 3 (3): • - $\mathrm{NaMg}_{3}\left[\mathrm{AlSi}_{3} \mathrm{O}_{10}\right](\mathrm{OH})_{2} \cdot 4 \mathrm{H}_{2} \mathrm{O}$, « $\mathrm{CaCO}_{3}, \mathbf{-}-\mathrm{SiO}_{2}, \boldsymbol{-}-\mathrm{FeO},--\mathrm{Fe}_{2} \mathrm{O}_{3},-\mathrm{Fe}_{3} \mathrm{O}_{4}$

The structural and sorption characteristics as measured by Nitrogen adsorption-desorption is listed in Table 2. The value of specific surface area of modified saponite by nanoscale magnetite particles is higher in comparison to natural clay. The share of micropores and especially mesopores in MCS 3 sample has increased, what can be explained by the formation of layered structure due to sorption nanosized magnetite in macropores of natural material.

So, the value of MCS 3 mesopores volume was $60,5 \%$ of the total pore volume. Thus, MCS 3 there is mesoporous sorbent with a maximum pore diameter 4,0-4,5 nm (Fig. 3).

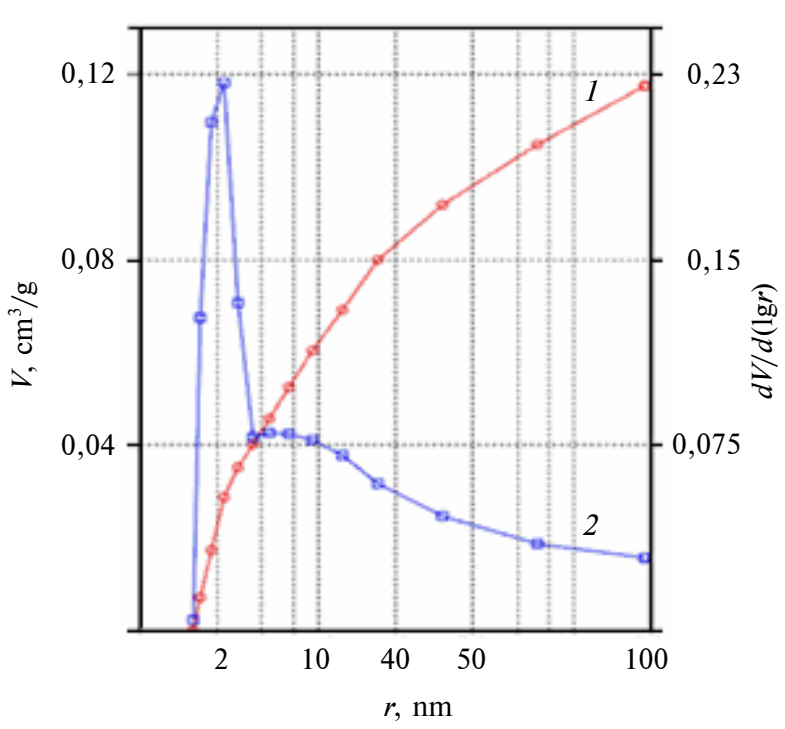

Fig. 3. Dependence of pore volume (1) and pore size distribution $d V / d \lg (r)=f(r)(2)$ on radius for MCS 3

The predominant mesopores diameter of MCS 3 is commensurate with characteristic size molecules of organic dyes: for Malachite green $1.3 \mathrm{~nm}$, Congo red $-2.5 \mathrm{~nm}$, Indigo carmine $1.2 \mathrm{~nm}$. The geometric optimization of organic dyes molecules has been carried out in $\mathrm{Hy}-$ perChem program.

Adsorption experiments. The adsorption capacity of simples was found from isotherms of dyes (Malachite green, Congo red and Indigo carmine) and presented in Table 3.

According to the data in table 3, MCS samples have higher adsorption capacity than native saponite. Also, it was found that MCS 3 was more effective at low concentrated water solutions (less than $1 \mathrm{~g} / \mathrm{dm}^{3}$ ). At the same time, the removal degree of Malachite green, Congo red, and Indigo carmine by sample MCS 3 was 99.9, 97, $99 \%$ respectively. Based on these data the further adsorption studies were carried out only on the MCS 3.

Table 2. Structural and sorption characteristics of simples

\begin{tabular}{|l|c|c|c|}
\hline \multicolumn{1}{|c|}{ Parameter } & Saponite & MCS 2 & MCS 3 \\
\hline Specific surface area $S, \mathrm{~m}^{2} / \mathrm{g}$ & 34.6 & 40.7 & 51.0 \\
\hline Micropore surface area $S_{\text {micro }}, \mathrm{m}^{2} / \mathrm{g}$ & 9.6 & 17.20 & 15.2 \\
\hline External surface area $S_{\text {ext }}, \mathrm{m}^{2} / \mathrm{g}$ & 25.1 & 23.5 & 35.8 \\
\hline Total pore volume $V_{\text {total }}, \mathrm{sm}^{3} / \mathrm{g}$ & 0.125 & 0.134 & 0.139 \\
\hline Micropore volume $V_{\text {micro }}, \mathrm{sm}^{3} / \mathrm{g}$ & 0.016 & 0.018 & 0.022 \\
\hline Mesopore volume $V_{\text {meso }}, \mathrm{sm}^{3} / \mathrm{g}$ & 0.031 & 0.024 & 0.084 \\
\hline Macropore volume $V_{\text {macro }}, \mathrm{sm}^{3} / \mathrm{g}$ & 0.078 & 0.092 & 0.033 \\
\hline Average pore diameter $d, \mathrm{~nm}$ & 12.0 & 10.9 & 9.4 \\
\hline
\end{tabular}


Table 3. The adsorption capacity of natural saponite clay and MCS simples

\begin{tabular}{|c|c|c|c|}
\hline \multirow{2}{*}{ Simple } & $\begin{array}{c}\text { Malachite } \\
\text { green }\end{array}$ & $\begin{array}{c}\text { Congo } \\
\text { red }\end{array}$ & $\begin{array}{c}\text { Indigo } \\
\text { carmine }\end{array}$ \\
\cline { 2 - 4 } & \multicolumn{3}{|c|}{$\Gamma, \mathrm{mg} / \mathrm{g}$} \\
\hline Saponite clay & 105.7 & 30.7 & 62.1 \\
\hline MCS 2 & 202.1 & 76.9 & 127.6 \\
\hline MCS 3 & 159.1 & 73.1 & 110.3 \\
\hline
\end{tabular}

Fig. 4 shows the kinetics of the adsorption process dyes by MCS 3. As seen on Fig. 4 the equilibrium was established for 60 minutes. MCS 3 is the most selective towards dyes of cationic type (Malachite green).

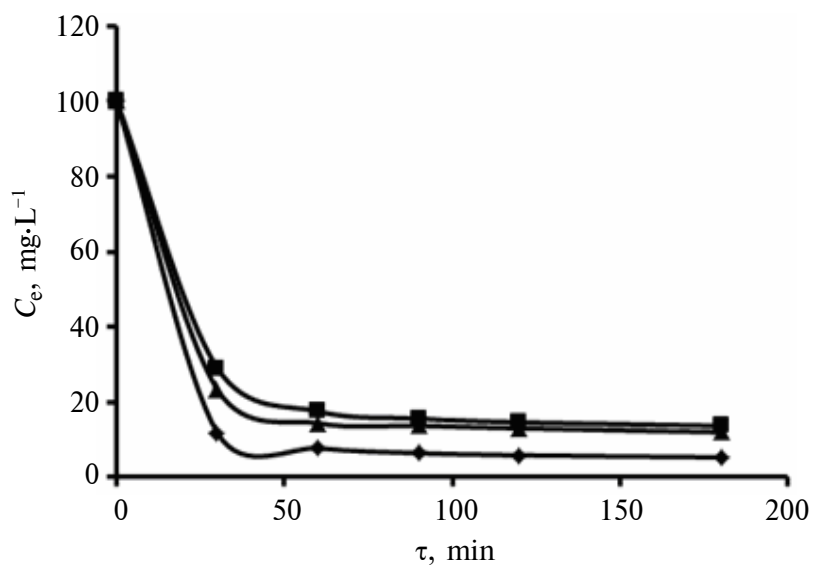

Fig. 4. The residual dyes concentration depending on the sorption time on MCS 3: - Malachite green; - - Congo red; $\boldsymbol{\wedge}$ - Indigo carmine

Magnetic separation. The two of magnetic modules designs were used for investigation of saponite and MCS samples deposition by magnetic se- paration (Fig. 5). The initial concentration of sorbent particles was $2000 \mathrm{mg} / \mathrm{dm}^{3}$.

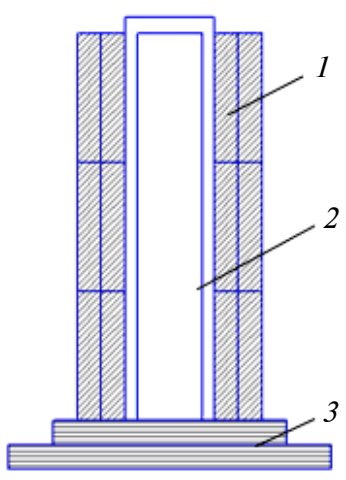

$a$

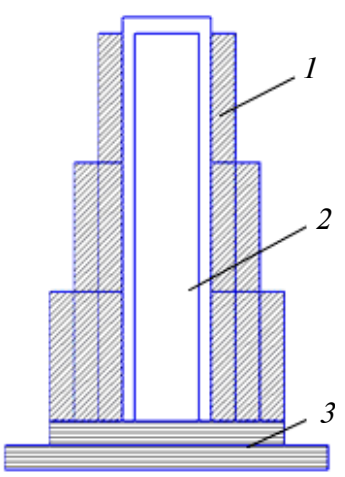

$\sigma$
Fig. 5. The magnetic modules designs: 1 - magnets; 2 - sorption reactor; 3 - body module: $a$ - double row magnetic module with invariable strength of the EMF of $66 \mathrm{mT} ; b$ - pyramid magnetic module with variable strength gradient of the EMF from 20 to $200 \mathrm{mT}$

The residual concentration of suspended particles of sorbents in two magnetic module designs is given in Table 4. As seen in Table 4, magnetic separation process of sorbent particles was more effective in pyramid magnetic module: the residual concentration of sorbent particles in pyramid magnetic module was 2-3 times less in comparison to double row magnetic module. Also, the residual concentration in both modules for MCS 3 was less than MCS 2, and for saponite clay it is more than for two MCS samples.

The deposition rate of particles for the first 30 minutes was calculated and accounted 42, 61 and $66 \mathrm{mg} /\left(\mathrm{dm}^{3} \cdot \mathrm{min}\right)$ for saponite clay, MCS 2 and MCS 3 respectively. Thus, the deposition rate of MCS samples in 1.5 times more compared with saponite clay.

Table 4. The residual concentration of suspended particles sorbents after magnetic separation

\begin{tabular}{|c|c|c|c|c|c|c|}
\hline \multirow{3}{*}{$\tau, \min$} & \multicolumn{3}{|c|}{ Double row magnetic module } & \multicolumn{3}{|c|}{ Pyramid magnetic module } \\
\hline & Saponite & MCS 2 & MCS 3 & Saponite & MCS 2 & MCS 3 \\
\hline & \multicolumn{6}{|c|}{$C, \mathrm{mg} / \mathrm{dm}^{3}$} \\
\hline 0 & 2000 & 2000 & 2000 & 2000 & 2000 & 2000 \\
\hline 5 & 559 & 222 & 225 & 419 & 234 & 252 \\
\hline 10 & 515 & 188 & 171 & 354 & 166 & 167 \\
\hline 30 & 388 & 162 & 87 & 264 & 155 & 95 \\
\hline 60 & 327 & 144 & 49 & 241 & 119 & 58 \\
\hline 90 & 310 & 143 & 34 & 229 & 115 & 32 \\
\hline 120 & 301 & 141 & 33 & 222 & 113 & 23 \\
\hline 150 & 298 & 137 & 28 & 207 & 83 & 20 \\
\hline 180 & 289 & 108 & 27 & 154 & 53 & 9 \\
\hline
\end{tabular}




\section{Conclusion}

It was found that modification of saponite by magnetite in an amount of $2 \%$ by weight not only improves its magnetic properties, but also increases its absorption characteristics (specific surface area, sorption capacity). The impregnation method allows obtaining magnetic clay sorbent with better sorption and magnetic characteristics. The sample (MCS 3) obtained by this method had removed dyes better from low concentrated solutions (less than $1 \mathrm{~g} / \mathrm{dm}^{3}$ ).
The adsorption properties of saponite clay and MCS samples were studied towards cationic and anionic dyes. The MCS 2 and MCS 3 had better absorption properties. The pyramid magnetic module was the most effective magnetic module design for deposition of spent magnetic sorbent.

In the future we plan to create magnetic composite sorbents on different mineral matrices to reduce the cost of the final product.

\section{List of literature}

1. Zidane F., Drogui P. Decolourization of dye-containing effluent using mineral coagulants produced by electrocoagulation // J. Hazardous Mater. - 2008. - 155. - P. 153-163.

2. Combination of advanced oxidation processes and biological treatments for wastewater decontamination: a review/ I. Oller, S. Malato, J.A. Sanchez-Perez et al. // Sci. Total Environ. - 2011. - 409. - P. 4141-4166.

3. Advanced treatment of textile wastewater towards reuse using a membrane bioreactor / M. Brik, P. Schoeberl, B. Chamam et al. // Process Biochem. - 2006. - 41. - P. 1751-1757.

4. Ramesh B.B., Parande A.K., Raghu S. Removal of a basic textile dye from aqueous solution by adsorption on regenerated clay // Procedia Engineering. - 2012. - 33. - P. 303-312.

5. Wawrzkiewicz M., Hubicki Z. Removal of tartrazine from aqueous solutions by strongly basic polystyrene anion exchange resins // J. Hazardous Mater. - 2009. - 164. - P. 502-509.

6. Dye and its removal from aqueous solution by adsorption: A review / M.T. Yagub, T.K. Sen, S. Afroze et al. // Adv. Colloid Interface Sci. - 2014. - 209. - P. 172-184.

7. Mui E.L. Dye adsorption onto activated carbons from tyre rubber waste using surface coverage analysis // J. Colloid Interface Sci. - 2010. - 347. - P. 290-300.

8. Rafatullah M. Adsorption of Methylene Blue on low-cost adsorbent // J. Hazardous Mater. - 2010. - 177. - P. 70-80.

9. Rytwo G. Use of CV- and TPP-montmorillonite for the removal of priority pollutants from water // Applied Clay Sci. 2007. - 36. - P. 182-190.

10. Conceição V., Freire F.B., Carvalho K.Q. Treatment of textile effluent containing indigo blue dye by a UASB reactor coupled with pottery clay adsorption // Acta Scientiarum. Technol. - 2013. - 35. - P. 53-58.

11. Magnetic composite an environmental super adsorbent for dyesequestration: A review/ R.Sivashankar, A.B.Sathya, K. Vasantharaj et al. // Environmental Nanotechnology, Monitoring Management. - 2014. - 2. - P. 36-49.

\section{References}

1. F. Zidane and P. Drogui,"Decolourization of dye-containing effluent using mineral coagulants produced by electrocoagulation”, J. Hazardous Mater., vol. 155, pp. 153-163, 2008. http://dx.doi.org/10.1016/j.jhazmat.2007.11.041

2. I. Oller et al., "Combination of advanced oxidation processes and biological treatments for wastewater decontamination: a review”, Sci. Total Environ., vol. 409, pp. 4141-4166, 2011. http://dx.doi.org/10.1016/j.scitotenv.2010.08.061

3. M. Brik et al., "Advanced treatment of textile wastewater towards reuse using a membrane bioreactor", Process Biochem., vol. 41, pp. 1751-1757, 2006. http://dx.doi.org/10.1016/j.procbio.2006.03.019

4. B.B. Ramesh et al., "Removal of a basic textile dye from aqueous solution by adsorption on regenerated clay", Procedia Engineering, vol. 33, pp. 303-312, 2012. http://dx.doi.org/10.1016/j.proeng.2012.01.1208

5. M. Wawrzkiewicz et al., "Removal of tartrazine from aqueous solutions by strongly basic polystyrene anion exchange resins", J. Hazardous Mater., vol. 164, pp. 502-509, 2009. http://dx.doi.org/10.1016/j.jhazmat.2008.08.021

6. M.T. Yagub et al., "Dye and its removal from aqueous solution by adsorption: A review", Adv. Colloid Interface Sci., vol. 209, pp. 172-184,2014. http://dx.doi.org/10.1016/j.cis.2014.04.002

7. E.L. Mui, "Dye adsorption onto activated carbons from tyre rubber waste using surface coverage analysis", J. Colloid Interface Sci., vol. 347, pp. 290-300, 2010. http://dx.doi.org/10.1016/j.jcis.2010.03.061

8. M. Rafatullah, "Adsorption of Methylene Blue on low-cost adsorbents", J. Hazardous Mater., vol. 177, pp. 70-80, 2010. http://dx.doi.org/10.1016/j. jhazmat. 2009.12.047 
9. G. Rytwo, "Use of CV- and TPP-montmorillonite for the removal of priority pollutants from water", Applied Clay Sci., vol. 36, pp. 182-190, 2007. http://dx.doi.org/10.1016/j.clay.2006.04.016

10. V. Conceição et al., "Treatment of textile effluent containing indigo blue dye by a UASB reactor coupled with pottery clay adsorption”, Acta Scientiarum Technol., vol. 35, pp. 53-58, 2013. http://dx.doi.org/10.4025/actascitechnol.v35i1.13091

11. R. Sivashankar et al., "Magnetic composite an environmental super adsorbent for dyesequestration: A review", Environmental Nanotechnology, Monitoring Management, vol. 2, pp. 36-49, 2014. http://dx.doi.org/10.1016/j. enmm.2014.06.001

\section{О.В. Макарчук, Т.А. Донцова, І.М. Астрелін}

\section{МАГНІТОКЕРОВАНИЙ СОРБЕНТ НА ОСНОВІ ГЛИНИ ДЛЯ ВИДАЛЕННЯ БАРВНИКІВ ІЗ ВОДНИХ РОЗЧИНІВ}

Проблематика. Сорбенти на основі сапонітової глини є дешевими і водночас ефективними відносно органічних забруднювачів, барвників, іонів важких металів. Проте сапонітова глина як сорбент широко не використовується через складність її видалення з води після процесу сорбції. Для подолання цієї трудності частинки глини можуть бути модифіковані магнетитом, що дасть змогу легко видалити їх із води магнітною сепарацією.

Мета дослідження. Метою дослідження є створення магнітокерованих сорбентів на основі сапоніту і магнетиту за різними схемами, їх характеризація та вибір конструкції магнітного модуля.

Методика реалізації. Було використано сучасні фрізико-хімічні та експериментальні методи дослідження: рентгенівську флуоресценцію, рентгеноструктурний аналіз, фрізичну адсорбцію/десорбцію азоту, експериментальні дослідження з адсорбції та магнітної сепарації.

Результати досліджень. Встановлено, що модифікація сапоніту магнетитом (2 \% від маси) методом просочування дає змогу отримати мезопористі сорбенти з високими сорбційними та магнітними властивостями. Виявлена адсорбційна ємність магнітокерованих сорбентів для всіх типів барвників (аніонних, катіонних і неіоногенних) становила в 1,5-2,5 разу більше, ніж для нативного сапоніту.

Висновки. Показано, що модифікація сапоніту магнетитом не тільки збільшує його магнітні властивості, але й покращує сорбційно-структурні характеристики. Магнітокерований сорбент, отриманий способом просочування, є більш ефективним при видаленні барвників із низькоконцентрованих розчинів барвників. Найбільш ефективно магнітокерований сорбент видаляється в пірамідальному магнітному модулі.

Ключові слова: сапоніт; магнетит; барвники; магнітокеровані сорбенти; адсорбція; магнітна сепарація.

\section{О.В. Макарчук, Т.А. Донцова, И.М. Астрелин}

\section{МАГНИТОУПРАВЛЯЕМЫЙ ГЛИНОСОДЕРЖАЩИЙ ГЛИНИСТЫЙ СОРБЕНТ ДЛЯ УДАЛЕНИЯ КРАСИТЕЛЕЙ ИЗ ВОДНЫХ РАСТВОРОВ}

Проблематика. Сорбенты на основе сапонитовой глины являются дешевыми и одновременно эффективными по отношению к органическим загрязнителям, красителям, ионам тяжелых металлов. Тем не менее сапонитовая глина как сорбент широко не используется из-за сложности ее удаления из воды после процесса сорбции. Для преодоления этой трудности частицы глины могут быть модифицированы магнетитом, что позволит достаточно легко удалить их из воды магнитной сепарацией.

Цель исследования. Целью исследования является создание магнитоуправляемых сорбентов на основе сапонита и магнетита по различным схемам, их характеризация и выбор конструкции магнитного модуля.

Методика реализации. Были использованы современные физико-химические и экспериментальные методы исследования: рентгеновская флуоресценция, рентгеноструктурный анализ, физическая адсорбция/десорбция азота, экспериментальные исследования по адсорбции и магнитной сепарации.

Результаты исследований. Установлено, что модификация сапонита магнетитом (2 \% от массы) методом пропитки позволяет получить мезопористые сорбенты с высокими сорбционными и магнитными свойствами. Обнаруженная адсорбционная емкость магнитоуправляемых сорбентов для всех типов красителей (анионных, катионных и неионогенных) была в 1,52,5 раза больше, чем для природного сапонита.

Выводы. Показано, что модификация сапонита магнетитом не только увеличивает его магнитные свойства, но и улучшает сорбционно-структурные характеристики. Магнитоуправляемый сорбент, полученный методом пропитки, является более эффективным при удалении красителей из низкоконцентрированных растворов красителей. Наиболее эффективно магнитоуправляемый сорбент удаляется в пирамидальном магнитном модуле.

Ключевые слова: сапонит; магнетит; красители; магнитоуправляемые сорбенты; адсорбция; магнитная сепарация.

Рекомендована Радою

хіміко-технологічного факультету

НТУУ "КПІ"
Надійшла до редакції

3 липня 2015 року 